\title{
The ethical dimension of Islamic urban architectural heritage as sustainable design
}

\author{
Dr. B. Belmessaoud -Boukhalfa \\ Polytechnic School of Architecture and Urban Planning, Algiers, Algeria
}

\begin{abstract}
The paper aims to contribute to the identification of the nature and the role of the ethical dimension of an urban form as an important determinant of design. Commonly, ethics is the most important of the intangible means to attain sustainability. Sustainability has to do firstly with intangible means of human needs and its comprehensive relationship with them. Environmental Ethics is the first theme in critical theory that aims to develop a less antagonist relationship with nature. In urban design, the main function of ethics is to prevent spatial dysfunctions due to the misuse of space in order to resolve social conflicts for human well-being. A practitioner s response to the various ethical dilemmas will not only need to be conditioned by the codes of conduct of the professional institution but also through the explicit recognition of the very different set of ethical values that should be integrated in designing projects. The paper focuses on Islamic urban architecture through the return to the authentic Islamic architecture as an extension of a long dialogue between the Islamic world and its architectural heritage. The paper aims at analyzing and clarifying the different ethical values concretized in Islamic civilization, to point to the architectonic and urban elements by which they were embodied. The approach is a detailed and significant review of existing literature. It includes the documentation concerning the urban and architectural heritages which have directly faced the theme of Islamic ethics. The paper contributes with a guideline to the broader appreciation of the ethical aspects of urban space that may be encountered in contemporary Islamic design practice. The paper can inform designers, conservation consultants, administrators and educators.

Keywords: Islamic architecture, urban design, ethics, urban elements, ethical values, sustainability.
\end{abstract}




\section{Introduction}

Currently with all the fast changes, it is a challenge to satisfy the demand in continual moving of the society. So it is imperative for a given society to preserve pinpoints from previous time that could serve as references for its development. In this frame of mind, the preoccupation of research is to find a guideline for the designer, a foundation of design principles able to respond to the present and future society's desire of modernity, but also to the ethical aspects indispensable to the happiness of these same societies and not an arsenal of freezing shapes. All civilizations over history have a heavy heritage of ethics. The task is to discern how this heritage was embodied. In the Arab world, the physical presence of a vast and varied architectural heritage which has not been integrated into the international language and culture of architecture remains a challenge to all architects building The traditional built environment still has valuable lessons for the architects and designers in creating new environments, but the prospects of its survival are uncertain [1]. It is a set of inherent rules in a specific society that explain how built space made to 'behave' in a certain way conveys information [2]. In this way, a designed space no longer remains just a geometrical compositional of forms and textures, but assumes associational codes for the people using them. The aim of this research is to depict these architectural principles of design underlying the Islamic ethical values to guarantee their preservation over time to future generations.

\section{The character of ethics and values}

It is suitable to clarify the term of ethics in this framework. Firstly, it is an illusion to suppose that ethical considerations can be sidelined [3]. Ethics are crucial because they are behind all value judgment. But, there is a distinction to be drawn between judgements of value and judgements of taste [3]. A value judgment does not express a personal preference, it is an assessment according to criteria as objective as possible. It is as if it compares any object to what would be the ideal object, which would lead to perfection. On contrary, a judgement of taste is personal. "Beauty is not a quality inherent in things themselves, it exists only in the mind which contemplates it and each mind perceives a different beauty" as asserted by Hume [4]. The esthetical good might elevate the human spirit but lacks the power of obligations embedded in ethics. Ruskin points to the fact that aesthetics of space even successful is not the task of the designer but the substance must be given to the ethical role of this sublimity [5]. This statement is reinforced by Lynch when he adds that it is the characteristic way of arranging space, activity and material that is linked to an idea of how a place is to be used and what it should express [6].

Ethics is a "métamorale", a doctrine beyond morality, a theory reasoned on the good and the evil, the values and the moral judgments. Ethics deconstruct the codes of behavior to endeavour to find the hidden basis of the obligation. They set statement of ultimate principles or basis. They are related to the theory and the foundation, the very basis of the prescriptions or moral judgments. Morality 
is a whole of suitable rules for a culture. Moral relates to the individual behavior and gather the social regulations and ethics works out the basis of the codes of manners; built a rational theory of the good and evil [7]. In Arabic, it is derived from the words of khuluq which means to create, to shape and to give form; Akhlaq -corresponding to ethics- is a subject of Ilm al-akhlaq. Akhlaq embraces all of the details of human character and life. It describes not only the religious injunctions containing the beliefs, but also gives a map of social behavior Muslims adhere to. Ilm al-Akhlaq is a branch of knowledge which deals with the rules and norms to increase human values and virtues, to avoid misconduct and to do what is correct [8].

The existence of value involves three necessary entities: (1) the object that has a value, (2) the subject for whom the value of the object exists, and (3) the judge who makes the value judgment of the object. The mean of the various values in a distribution is used to represent the value, and that is called the "norm" of the value by social scientists [9]. In architectural and urban field, the norm can be an ideal city. In such case, the norm is built by a group of urban theorists and philosophers as an ideal city; the judge is the designer who takes in mind the ideal city and the needs of the contemporary society with the objective of an exemplary society. That's why it is a so significant responsibility.

\section{Content analysis}

\subsection{Ethical leg and Islamic city}

Ethics of Islamic urban civilization and its social order favored a strong community life as essential key of sustainability [2]. Islamic law 'Chari' $a$ ' sets an exemplary standard of ethics which could not be corrupted by arbitrary human interventions and preserves the primacy of God (Allah) as the real ruler and the only Legislator of the community. From the beginning, Islam had excluded the concept of sacred kingship with legislative authority and the role of the Islamic ruler was only to "promote the right and to prevent the evil" in accordance with the given Islamic law to be implemented. As man's relation to the universe is that of knowledge whereas man's relation with his God is that of allegiance and worship. Man is the first creation Allah created in the best of moulds and is considered as a standard of perfection in works carried out by mankind [10, Surat Tin: 3]. Nevertheless the Qur'an warned against excess and exaggeration (moderation) [10, Surat Ra'd: 19]. Many times the Qur'an and the Hadith emphasise humbleness and simplicity [10, Surat Luqman: 18].

So Islamic law constitutes rules of building determined by the codex of social behavioras and described in El Wansharisi's book which discusses cases of harm due to building activity. Religiously based, it did not originate from abstract principles but from the live experience of an exemplary society, its main concern was to promote an exemplary pattern of individual and collective human conduct. It implied a complete "positive" system of human behaviour including a codex of good manners [2]. Also, the great strength of Islamic art as a whole lies in its ability to synthesize native design elements with imported ones (ex. the city 
of Damascus). The goal of the Muslim art is to get nearer to the absolute and was the base of any building activity.

The city was a sort of container of human values and civilization features which define the traits of urban Islamic architecture. The principle of a justly balanced Ummah mentioned in the Qur'an has urged the architect to strike a just balance in his architecture and to set an example in architecture for people to follow. The commonly accepted rules of building, as determined by the codex of social behaviour combined with the casual freedom of individual variations resulted in the striking balance and homogeneity of the Islamic townscape which is so different from planned uniformity [2]. The lack of formal institutions resulted in the absence of outstanding government buildings and related formal open spaces. As a rule, public spaces lack the rigid layout which is imposed by highly formalized institutions, allowing for a high degree of interaction between various social activities, including religious functions. This reality gives a democratic character to the city as the adaptive re-use flexible and polyvalent use of space. In one place, social, religious, administrative and representational functions are related. Accordingly, the outer side of edifices was not given much importance while the inner part was much decorated. Thus, the architect and the urban designer were responsible in discouraging boasting and inequality in their architecture; for fear that others feelings should be motivated [11].

The human dimension on the basis of which cities and houses were built took into consideration environment (climate and pollution), living conditions (rest and security), and religious matters (culture and ethics). The Islamic city is marked by the dominance of the mosque founded at the centre of the city and surrounded by buildings. Most traditional Islamic cities, with the exception of royal palace cities, followed an "organic" pattern of growth, marked by the presence of certain archetypes of built form which acted as architectural "seeds" [2]. Such archetypes could develop a wide range of related physical shapes according to: site constraints, community size, economic resources and building materials etc., as components of urban form. This flexibility in designing and governing the city gives a democratic value to the city and its inhabitants but also gives individual freedom to the person. The community responsibility as the groups (family clans, foreign ethnic communities or professional corporations) allowed taking charge of the respective sections of public open space running through their "territory", in both residential districts and market areas.

Civilizational unity is the major reality enriched by the monotheistic Islamic religion. Unity is an agreement between members of a society that gives solidarity. The orientation of city buildings towards the Kiblah embodies the value of humility. Also embedding as it was in the framework of the central markets, the mosque seldom took monumental forms. Public open space was detached from the main arteries according to specific uses and to integrate it into corresponding public buildings, such as mosques, madrasas and caravanserais. Such hierarchy preserves the value of individual freedom by protecting privacy. Most of the institutional functions were fulfilled by the Mosque, the prime public building which had not only religious but all sorts of political and social functions. Such public spaces concretize democracy and solidarity values. While 
being the major religious building, it usually remained a polyvalent structure integrated into the urban fabric, with no intention of expressing the power of religious or secular authorities [2]; centre of spiritual interaction and information exchange, performing the functions of conference halls open to the public. The values controlling the people behavior were being thought there.

These values were also manifest in the height of houses which does not rise above that of the mosque with its minarets and domes, whereas buildings of great size are an expression of power [12]. Houses are made up of two floors and don't rise above the other so that neighbours do not violate the privacy of the other. The façades adopt a humble look reflecting the qur'anic verse: "Nor walk in insolence through the earth", as opposed to the inner parts of houses [10, Surat Insan : 14]. The closely interlocked pattern of Muslim neighbourhoods also relates to the fact that ostentatious display of wealth and power was branded as arrogance by the social code of Islam. Wealth regarded as a distinction bestowed on an individual, but also as something lent to him by the Lord; to be used in a socially acceptable form. These details strengthen the value of equity and consequently the value of solidarity. Spending funds on artistic decoration of the house was licit. The architectural richness was mostly displayed within the walls as an element enhancing the idea of the sacred interior space of home. Ornamentation principle when well used guarantees the feel for the person to be free, whereas exteriorizing was considered as inappropriate or of bad taste because Islamic wisdom focuses on content not on exterior appearance. This care reinforces equity between members of a given society and does not lead to bad feelings of injustice.

While the architectural fabric tends to be continuous, it also shows a clear internal differentiation into a series of self-contained cellular compartments, which allow the private or sacred character of individual spaces to be protected where and when needed. This quality contributes to the value of individual freedom and permits solidarity. It also promotes equity which reinforces the feel of solidarity.

\section{Method}

The intellectual effort of the study stands on the aptitude of interpreting urban concepts (geometry, characters, architectural-urban elements and functions) in light of ethical values. The approach rests firstly on the understanding of the ethical value to enlighten the very relationship with the urban phenomenon multiple facets; the questions concerns: a) the spatial characteristics of the urban space, b) its urban and architectural elements, c) its geometric form, d) the definition of the activity pattern sustaining the selected ethical values, e) the record of the urban character by describing it in words and pictures using the visual vocabulary alluded to above [13], f) evaluating the relationship between the two variables (ethical value and urban element) by introducing rules for ranking scale from axiological principles [14] and in reference to a norm model. The norm model shows that human perception and urban qualities are involved in the implementation of the ethical values as guiding principles of the city design in many levels [15]. 
Table 1: Urban characters and elements of Humility (Submission; no evident civic pride).

\begin{tabular}{|c|c|c|c|}
\hline $\begin{array}{c}\text { Urban } \\
\text { concepts }\end{array}$ & $\begin{array}{c}\text { Urban } \\
\text { characters }\end{array}$ & Archi./ Urban Elements & Functions \\
\hline Mosque & Openness (roof and enclosed & Pillared hall & Worship (collectively) \\
\hline \multirow{5}{*}{ Madrasa } & space) & Large courtyard (sahn) & Religious \\
\hline & Accessibility (permeability) & Shaded arcades (riwaqs) & Purification (absolutions) \\
\hline & $\begin{array}{l}\text { Verticality Dominance Purity } \\
\text { Integration }\end{array}$ & $\begin{array}{l}\text { Minaret (sole verticality) } \\
\text { Large domes }\end{array}$ & $\begin{array}{l}\text { Symbolism of eternal life and } \\
\text { aesthetic Necessary ablutions }\end{array}$ \\
\hline & $\begin{array}{l}\text { Polyvalence (merge functions } \\
\text { of forum and temple) }\end{array}$ & $\begin{array}{c}\text { Number of entries gates } \\
\text { Thresholds } \\
\text { Exterior -Interior } \\
\text { Impure - Pure } \\
\text { large central courtyard }\end{array}$ & $\begin{array}{l}\text { before prayer Protection of the } \\
\text { ritual purity of the Mosque space } \\
\text { Meeting / civic functions }\end{array}$ \\
\hline & $\begin{array}{c}\text { Flexibility } \\
\text { Polarity } \\
\text { Orientation (Mecca) }\end{array}$ & $\begin{array}{l}\text { shaded arcades } \\
\text { Profane - Sacred } \\
\text { Noise }- \text { Silence } \\
\text { Light }- \text { Shadow }\end{array}$ & $\begin{array}{l}\text { No oppressive power or rules } \\
\text { (large amount of autonomy and } \\
\text { responsibility to various social } \\
\text { groups within the society) }\end{array}$ \\
\hline Houses & $\begin{array}{l}\text { No exterior ostentatious } \\
\text { decorations } \\
\text { Abstraction - simplicity: }\end{array}$ & $\begin{array}{l}\text { quibla wall facing Mecca } \\
\text {; a mihrab } \\
\text { pillared hall - tradition of } \\
\text { Roman market basilicas }\end{array}$ & $\begin{array}{l}\text { Absence of city planning in the } \\
\text { modern institutional sense. } \\
\text { (world fight-meditation) }\end{array}$ \\
\hline & Interior decoration & $\begin{array}{l}\text { Opposites interlink } \\
\text { fountains or wells }\end{array}$ & \\
\hline & & $\begin{array}{l}\text { Simple facades } \\
\text { Courtyard } \\
\text { Garden }\end{array}$ & \\
\hline House's & Openness & Fountain & Symbolism with heaven \\
\hline Garden & $\begin{array}{l}\text { Vertical connection Inward } \\
\text { looking } \\
\text { Interior ornamentation }\end{array}$ & & Purification \\
\hline
\end{tabular}

Table 2: Urban characters and elements of Democracy: Choura (function of asking counsel).

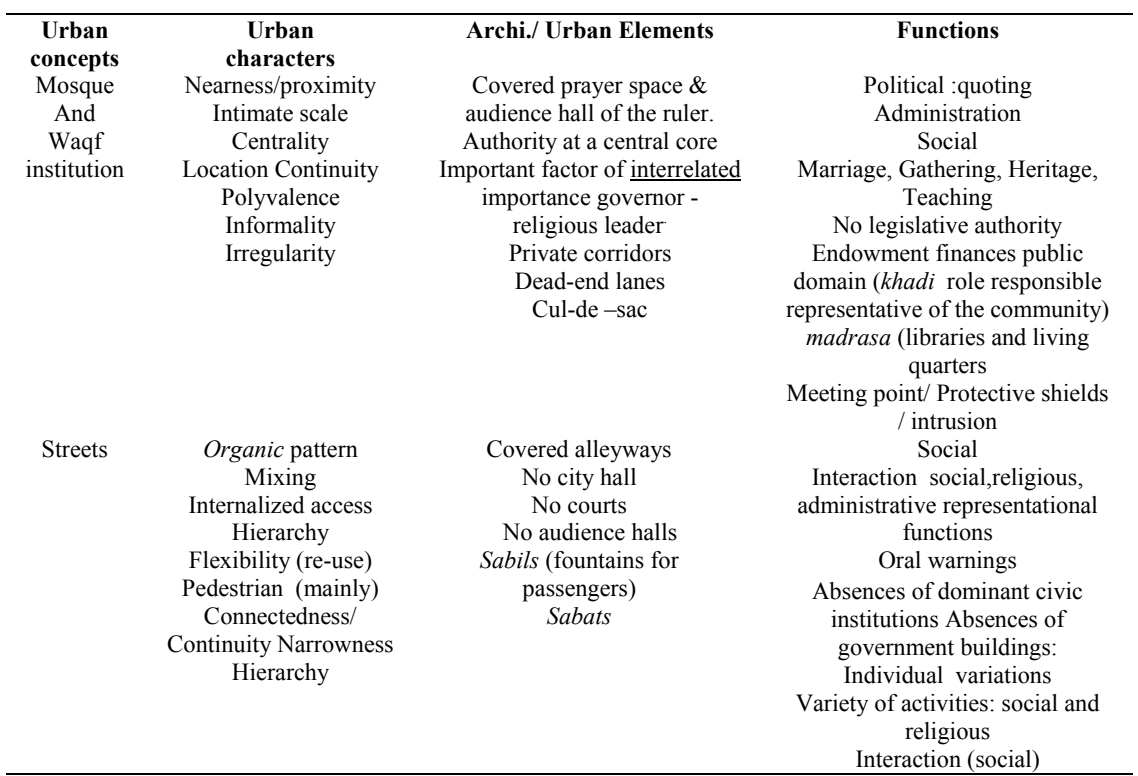


Table 3: $\quad$ Urban characters and elements of solidarity (author).

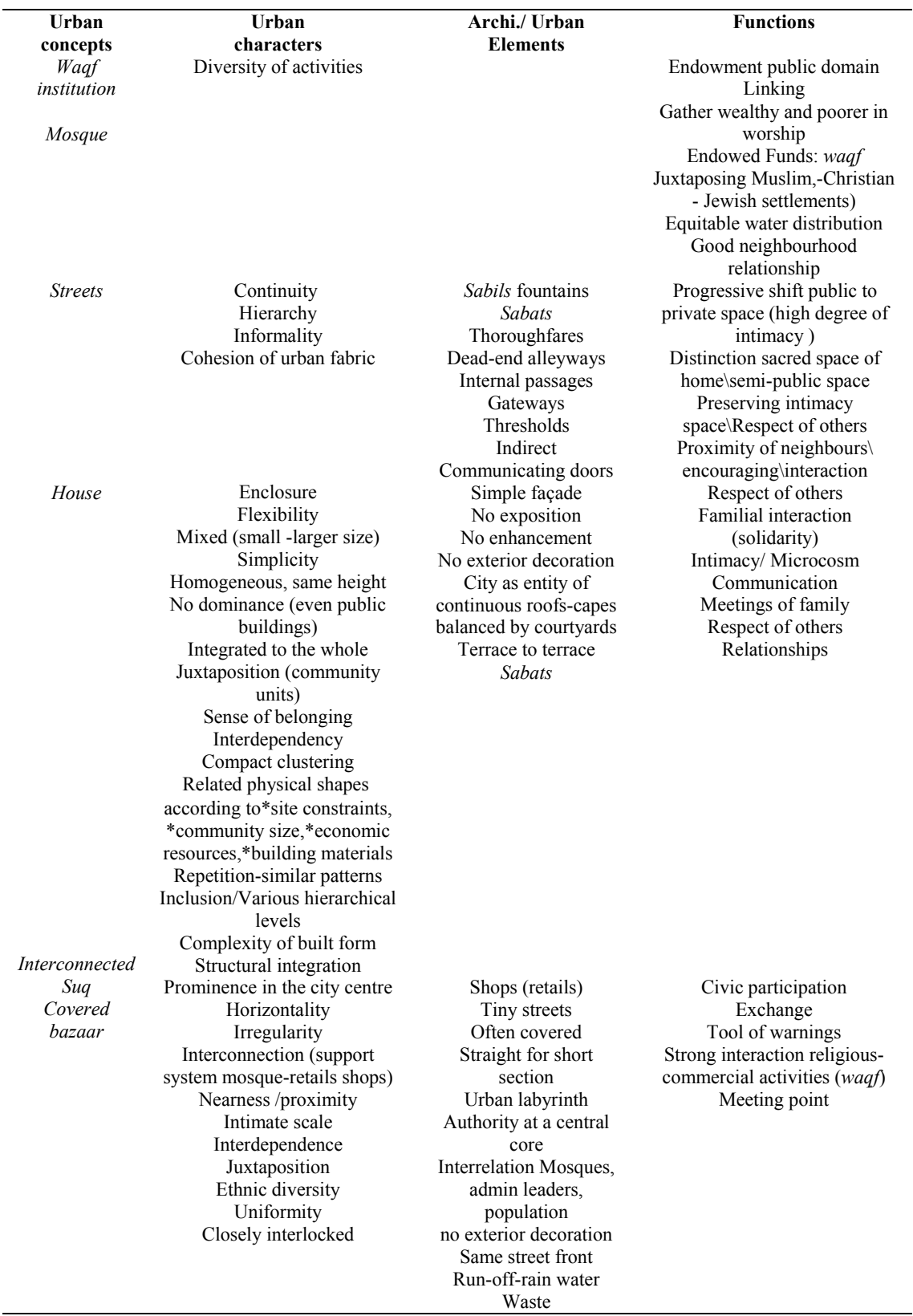

The main research objectives can be summarized by the following steps: 1) grasping through the historical evolution of the urban fabric the priorities held in the civilization; 2) concretizing the ethical values in urban concepts that lead 
to the emergence of indicators of good form (relevant and responsive). These urban concepts can then facilitate the restructuring of the future urban fabric. The different ethical values and their urban principles are developed in the tables:

Table 4: $\quad$ Urban characters and elements of equity (author).

\begin{tabular}{cccc}
\hline Urban concepts & Urban characters & $\begin{array}{c}\text { Archi./ Urban } \\
\text { Elements }\end{array}$ & Functions \\
Residential Districts & Decoration & Facades of houses, No & Sentiment of Justice \\
& Horizontality & ostentatious display of & Security \\
& Mixing larger and & wealth & Privacy \\
& smaller houses & Drainage channels & Self-expression \\
& Simplicity & (network) & Just water distribution \\
& Equitable mechanism & Prayer hall & Worship \\
Mosque & Homogeneity & Courtyard & Meet others \\
& townscape: balance & Smaller door & Belonging \\
& publiclprivate spaces & incorporated into the big & Meeting \\
& Centrality & gate, minimizing & \\
& Inward looking & opening & \\
& Enclosure & &
\end{tabular}

Table 5: $\quad$ Urban characters and elements of individual freedom (author).

\begin{tabular}{|c|c|c|c|}
\hline $\begin{array}{c}\text { Urban } \\
\text { concepts }\end{array}$ & Urban characters & Archi./ Urban Elements & Functions \\
\hline \multirow[t]{8}{*}{$\begin{array}{l}\text { Individual } \\
\text { house }\end{array}$} & $\begin{array}{c}\text { Self- contained } \\
\text { Vertical connection }\end{array}$ & $\begin{array}{l}\text { Entry vestibules are positioned to } \\
\text { obstruct the view of the inner }\end{array}$ & $\begin{array}{l}\text { Protection from outside } \\
\text { Inviolability }\end{array}$ \\
\hline & Windowless façade & realm of the home. & Defence: acoustic- \\
\hline & Threshold & Fountain & environmental nuisances, \\
\hline & Interior decoration & Courtyard (courtyard open roof) & visual intrusion \\
\hline & Privacy & Veiled wooden (mushrabiya), or & Sacred family sphere, the \\
\hline & Individual variations & dissimulated by ornamental & Hearth \\
\hline & Autonomy of residential & patterns of the wall surface. & space to yourself \\
\hline & units & No visual corridor & Pure space and protected \\
\hline \multirow[t]{5}{*}{ Street } & Irregularity \Arrangement & Free artistic decoration (walls) & private domains, \\
\hline & Supremacy of private & Interior garden/ Parcel & \\
\hline & arrangement over public & & Avoid inappropriate mix \\
\hline & Reduction of circulation & & of activities. Sacredness \\
\hline & Major circulation streams & & \\
\hline \multirow[t]{2}{*}{ Mosque } & Centrality & Courtyard & Meeting $\backslash$ self-expression \\
\hline & Flexibility & Prayer hall & Worship \\
\hline \multirow[t]{2}{*}{ Suqs } & Irregularity & Parcours & Use and leisure \\
\hline & Diversity & & Promenade \\
\hline
\end{tabular}

\section{Assessment}

The evaluation set according to axiological principles and in reference to a norm model was developed as a theoretical urban model in previous research and showed all the urban elements in detail [15]; the choice was made in such method suitable to the difficulty to evaluate some urban characters in one hand and to the presence of some urban factors that do not appear in the urban system in other hand as the sociological elements (social funds, privilege of being citizen, access to citizen right ...). The recording method uses the extensionist approach to the evaluation and introduces rules for ranking. The ranking scale serves to evaluate the relationship between the two variables (ethical value and urban element), then to give weight to each relationship between ethical value 
and urban element by the value- density. The value can be positive or negative. An index of the value model is used for the purposes of comparing it with other models.

We agree to the commitment of view that any urban model that contains an infinite amount of good and has a positive value-density is better. Also to the assumption that, given a finite set of $n$ properties, a model is good if it is perceived to have all of the urban elements, fair if it has more than $\mathrm{n} / 2$ of them, average if $\mathrm{n} / 2$ of them, and bad if it has fewer than $\mathrm{n} / 2$ [16]. It is possible to find the existence of inverse that is elements $(-a)$ for every value, namely if it exists a positive value (a) there exists an element which is its inverse. The ranking scale rests between an absolute value of 6 (strongest), 0 (null) and a weakest negative value (-6). The next figures are organized in five sections according to the ethical values and the urban model. Each ethical value is an ensemble of urban elements that represent the properties of the system.

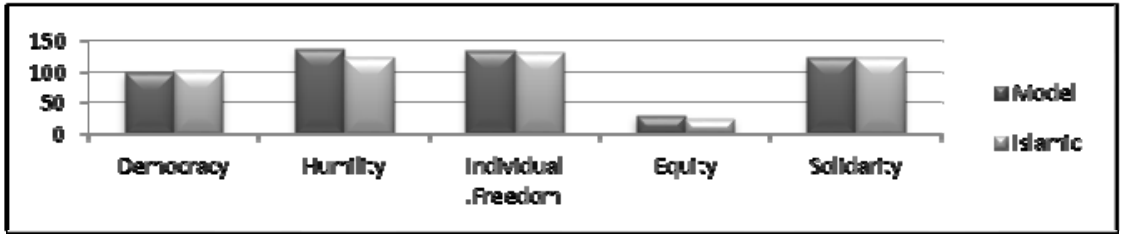

Figure 1: Comparison of the different ethical values by the richness of urban elements.

\section{Results and interpretation}

At the level of urban models, the hierarchy of richness shows the richness of the humility value. In this research, the richness means that a great number of urban elements should be thought about in conception. All the values were fulfilled, the reached score is superior to the half $(\mathrm{n} / 2)$, except for the equity which was fair $(>\mathrm{n} / 2)$ for the Islamic urban model. According to systematic dimension - the condition is to fulfil the idea or the definition [16] - the Islamic urban model has not fulfilled totally the properties of the theoretical model (Fig. 2) because the suggested urban model has been conceived more flexible for some urban elements (as for pedestrian movement which cannot reach the value of six, regarding the need for a suitable mechanical movement). But, the Islamic urban model has the main qualities for Equity. The analysis reveals also that the selected urban model has stressed on the values of humility, solidarity and individual freedom; and is good in the case of equity value (Fig. 6). 


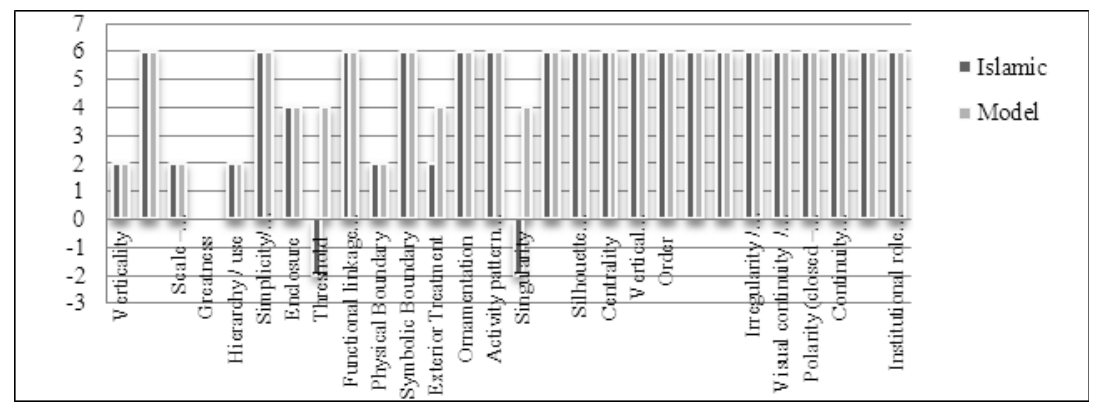

Figure 2: $\quad$ Results for humility value.

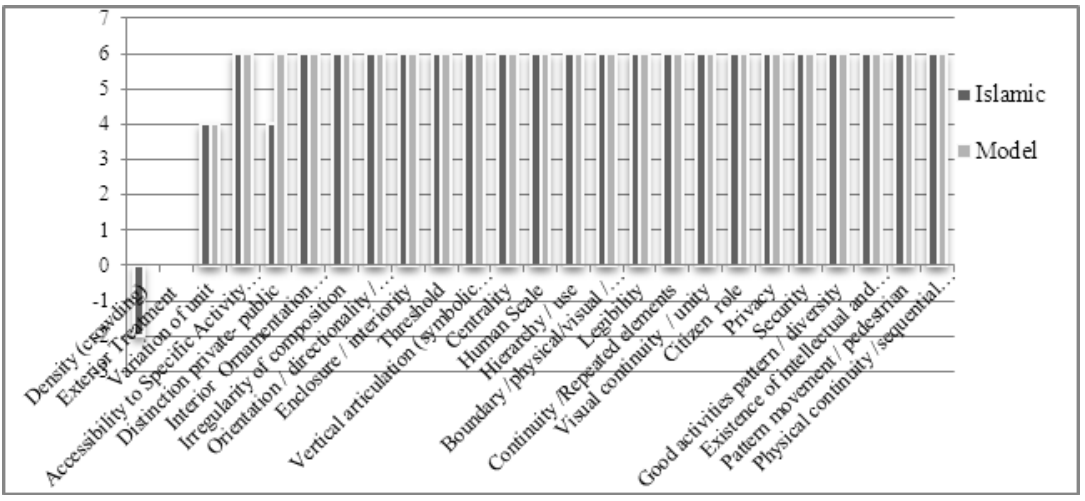

Figure 3: Results for individual freedom.

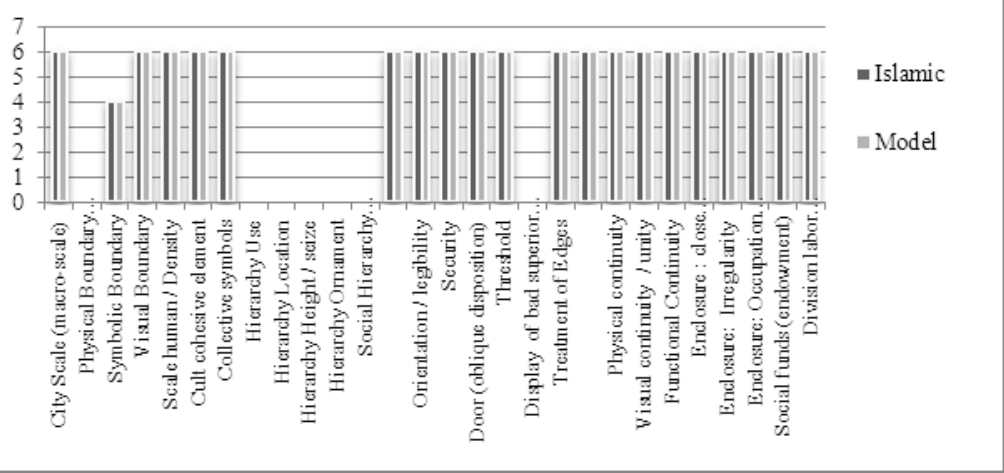

Figure 4: Results for solidarity value. 


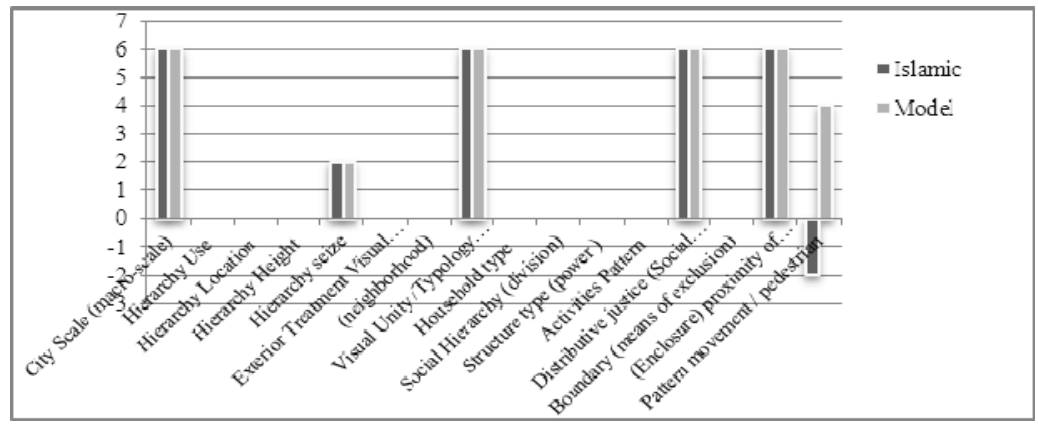

Figure 5: $\quad$ Results for democracy value.

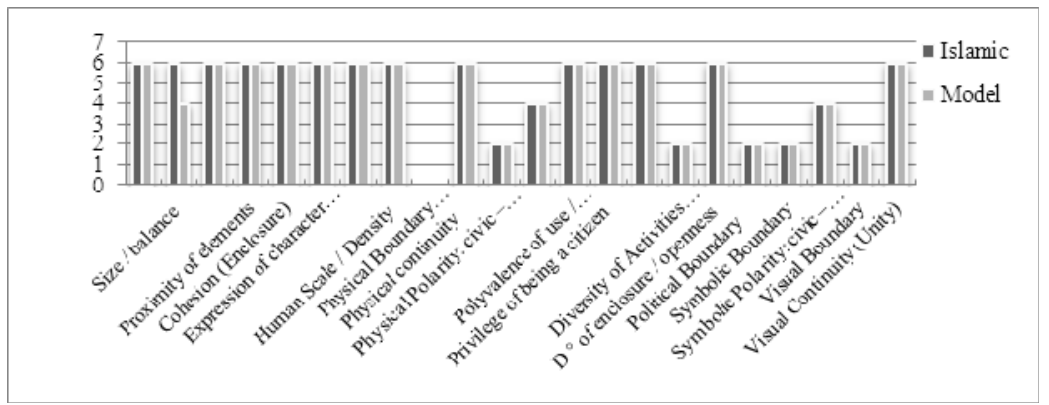

Figure 6: Results of equity value.

\section{Conclusion}

An ethical approach manages and creates a just balance between personal freedom and civic life and between personal and public space. This article analysed and clarified the core of ethical values embodied in the Islamic civilization. It enlightened the architectural and urban characters and the elements by which they were materialized. It has appeared from the evaluation that all the ethical values were present in different degree.

Three main aspects have an important role when dealing with ethical values: Space Typology which emphasizes the two types of spaces: man-made space and natural space; Scale of space: macro and micro scale and Perception of space that represents the spatial quality. The Islamic urban model has succeeded in creating just balance between communitarian values and individual freedom giving flexibility in some architectural mechanisms and rigidity in others. For example, ornamentation is permitted in public spaces but prohibited in exterior facades of personal or private spaces whereas it is permitted in the interior. It is the same concern for scale.

As a whole, the main quality is unity in diversity. Approximately, producing unity gives rise to humility and to equity by which solidarity emerges and diversity promotes individual freedom and democracy. In the past, the traditional 
Islamic urban model that embodied the Islamic ethical heritage has succeeded in producing a wise and intelligent individual and a good society.

\section{References}

[1] Holod R, Introduction in Architecture and Community, Holod R. editor, Aperture Publisher, USA, 1983.

[2] Bianca S., Urban form in the Arab world, past and present, Schriften, 2000.

[3] Holland A. and Rawles K.; The Ethics of Conservation: Report prepared and submitted to Countryside Council for Wales. Thingmount Working Paper Series on the Philosophy of Conservation, (unknown date); p. 4.

[4] Hume D., De la norme du goût, in Essais esthétiques, Paris, Editions G.F., 1755.

[5] Matteson, J., Constructing Ethics and the Ethics of Construction: John Ruskin and the Humanity of the Builder, Fall, 2002, Vol. 52, No 3.

[6] Lynch K., Good City Form, MIT Press, Cambridge, Mass., 1984, 1981.

[7] Russ J. La Pensée Ethique Contemporaine; Que Sait-je ? PUF 1994.

[8] Toguslu E., Gülen's Theory of Adab and Ethical Values of Gülen movement, p.446.

[9] Sheng C.L., A Utilitarian General Theory of Value, The Value Inquiry Book Series, Editions Rodopi, GA The Netherlands, Vol. 61, 1998, p. 34.

[10] Qur'an:

[11] Bahnassi A., Emphasizing Religious and Civilisational Features and Sublime Values in Islamic Arts, 2006 in www.isesco.org.ma.

[12] The Discipline of Architecture; Editors A. Piotrowski and J. Williams Robinson, Published by the University of Minnesota Press, 2001, pp. 86-87.

[13] Bell, S., Landscape Pattern, Perception and Process; E \& FN Spon Taylor \& Francis Group, 1999.

[14] Bostrom, N., Infinite Ethics, Faculty of Philosophy, Oxford University, 2004.

[15] Belmessaoud, B., Sustainability and Urban Form; implementing ethical values in sustainable urban design; edit. University of Alexandria, 2006, chap.III, IV.

[16] Hartman R. S., The Structure of Value: Foundations of Scientific Axiology, Southern Illinois University Press, 1967. 